\title{
Potassium Currents Distinguish the Two Subtypes of Morphologically Distinct Skate Bipolar Cells
}

\author{
HAOHUA QIAN ${ }^{1,2, *}$, RICHARD L. CHAPPELL ${ }^{1,3}$, STEPHEN REDENTI $^{1,3}$, \\ AND HARRIS RIPPS ${ }^{1,2}$ \\ ${ }^{1}$ Marine Biological Laboratory, Woods Hole, Massachusetts; ${ }^{2}$ University of Illinois at Chicago, \\ College of Medicine, Chicago, Illinois; and ${ }^{3}$ Hunter College and The Graduate Center, CUNY, \\ New York, New York.
}

Bipolar cells in the vertebrate retina are second-order neurons that convey visual information from photoreceptors to ganglion cells, the neurons that relay the message to the brain. Bipolar cells consist typically of multiple subtypes that differ in their morphology, synaptic connections, and response properties. The individual subtypes are thought to carry different aspects of the visual signal through the retina, and they often exhibit unique membrane properties and neurotransmitter receptors (1). In the all-rod skate retina, only two morphologically and pharmacologically distinct subtypes of bipolar cell have been identified thus far. The large-field bipolar cells, with extensive dendritic arbors, are glycine-insensitive, whereas the small-field bipolar cells, which have only one or two dendritic branches, are sensitive to glycine (2). In the present study, we explored further the membrane properties of these two subtypes of skate bipolar cell with emphasis on the voltagesensitive potassium currents. Our results show that the cells exhibit different voltage-activated current profiles, suggesting that the signals they transmit contain different features of the visual scene.

Solitary bipolar cells were prepared from skate retina according to the published protocol (3), and were approved by the IACUCs of the University of Illinois College of Medicine and the Marine Biological Laboratory, Woods Hole, Massachusetts. Briefly, skates (Raja erinacea) were anesthetized in $0.02 \%$ MS222 and double pithed following cervical section; the eyes were then enucleated and hemisected. After removing most of the vitreous, the retina

Received 1 September 2004; accepted 7 October 2004.

* To whom correspondence should be addressed at Department of Ophthalmology and Visual Sciences, University of Illinois at Chicago, 1855 West Taylor Street, Chicago, Illinois 60612. E-mail: hqian@uic.edu was gently peeled from the underlying tapetal region and incubated for $50 \mathrm{~min}$ in a modified culture medium containing $1.8 \mathrm{mg} / \mathrm{ml}$ papain (Calbiochem, La Jolla, CA) and 1 $\mathrm{mg} / \mathrm{ml} \mathrm{L}$-cysteine. The tissue was dissociated by trituration through a sterile pipette, and groups of isolated neurons were kept at $14{ }^{\circ} \mathrm{C}$ for up to one week in culture dishes containing an elasmobranch Ringer solution comprising (in $\mathrm{m} M$ ): $\mathrm{NaCl}$ (250), $\mathrm{KCl}$ (6), $\mathrm{MgCl}_{2}$ (1), $\mathrm{CaCl}_{2}$ (4), urea (360), glucose (10), and HEPES (5), titrated to $\mathrm{pH} 7.6$ with $\mathrm{NaOH}$. Whole-cell voltage clamp recordings were obtained from the cell bodies of individual bipolar cells using patch pipettes filled with a solution containing (in $\mathrm{mM}$ ): $\mathrm{KCl}$ (204), EGTA (11), $\mathrm{CaCl}_{2}$ (1), $\mathrm{MgCl}_{2}$ (1), and HEPES (10), titrated to $\mathrm{pH} 7.6$ with $\mathrm{KOH}$. Subtypes of bipolar cells were identified by their morphological appearance and their differential responses to glycine (2).

Skate bipolar cells are readily identified in culture. They have a pear-shaped cell body, from which a prominent axon emerges. The length of the axon is quite variable, perhaps reflecting $\mathrm{ON}$ and $\mathrm{OFF}$ cell types (4) and variation in the retinal regions from which the cells originate. At its distal end, the cell body extends dendrites whose pattern aids in distinguishing the two subtypes. Figure 1 illustrates several examples of the two subtypes found in the skate retina. Large-field bipolar cells extend several prominent branches with extensive dendritic arbors that enable them to receive input from many photoreceptors (Fig. 1A). In contrast, small-field bipolar cells contain one, or at most two, branches extending from a large dendritic process (Fig. 1B). In our previous study we reported that small-field bipolar cells are responsive to glycine, whereas large-field bipolar cells are glycine-insensitive (2); we obtained similar results in the present study (data not shown). 


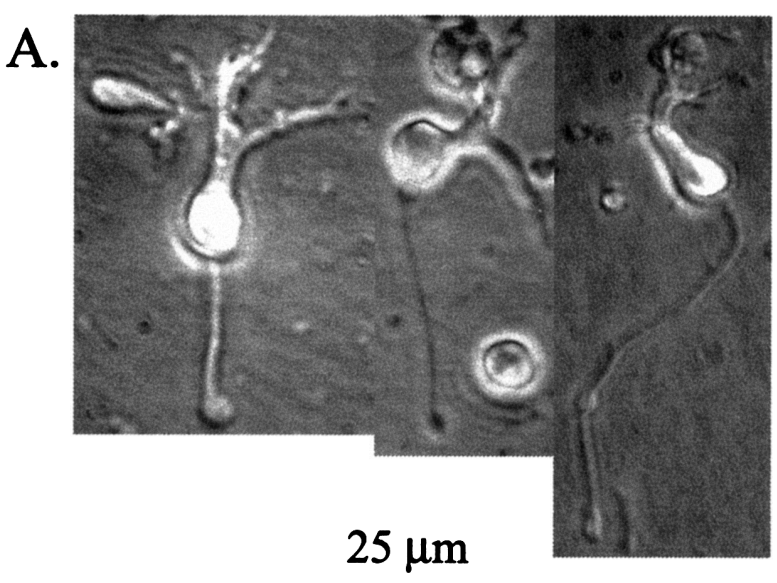

B.

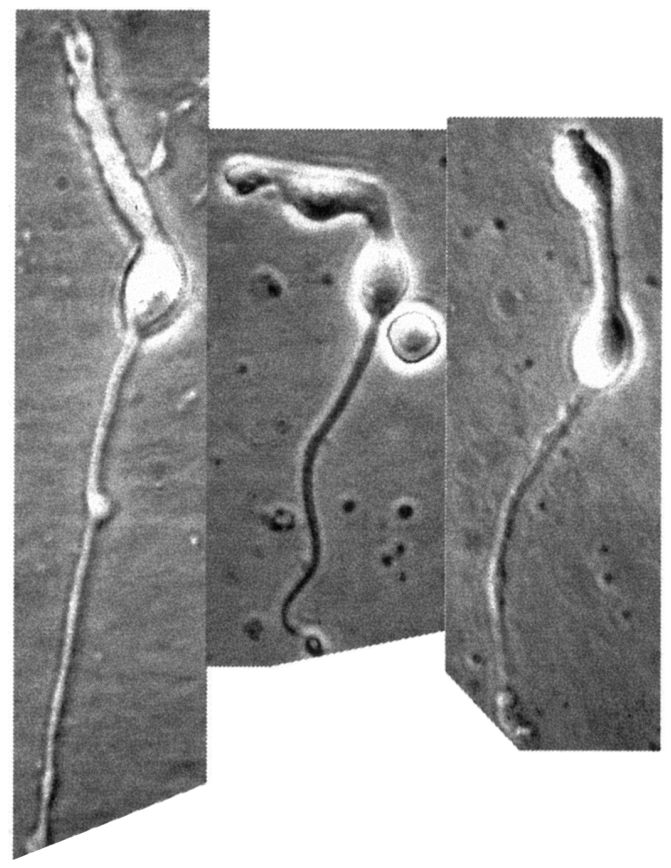

Figure 1. Examples of two morphological subtypes of bipolar cells isolated from skate retina. The two subtypes are distinguished by their dendritic pattern. (A) Large-field bipolar cells contain several small dendrites that arborize within the outer plexiform layer, and axons that extend downward to the inner plexiform layer of the retina. (B) Small-field bipolar cells have only one (or two) main dendrites.

Under whole-cell voltage clamp recording conditions, the small- and large-field bipolar cells exhibited different voltage-activated membrane currents. Figure 2A shows typical current recordings from cells held at $-60 \mathrm{mV}$ and stepped to membrane potentials from -120 to $+60 \mathrm{mV}$ in $20 \mathrm{mV}$ steps (inset). At voltages positive or negative to the resting potential $(-40 \mathrm{mV})$, small-field cells invariably gave rise to larger membrane currents than those of the large-field, glycine-insensitive cells. This is clearly evident in the averaged current-voltage relationships for small- and large-field cells shown in Figure 2B, in which the peak amplitudes are plotted as a function of transmembrane voltage. Note also that, although the I-V curves for both cell types display outward rectification, this is much more apparent in the recordings from small-field bipolar cells; i.e., low-amplitude membrane currents were elicited at hyperpolarizing voltages between -120 and $-40 \mathrm{mV}$, but as the magnitude of the depolarizing voltage steps increased from $-20 \mathrm{mV}$ to $+60 \mathrm{mV}$, the outward current responses grew linearly at a rate of $17.5 \mathrm{pA} / \mathrm{mV}$. Nevertheless, the outward currents elicited from both bipolar cell subtypes exhibit little timedependence.

On the other hand, the inward currents induced in smalland large-field bipolar cells by hyperpolarizing voltage steps differed both in amplitude and time course. The differences in amplitude are clearly evident in the I-V relations shown in Figure 2B. In Figure 3, which compares the time courses of the inward currents, the inset shows the almost instantaneous response of the small-field bipolar cells,

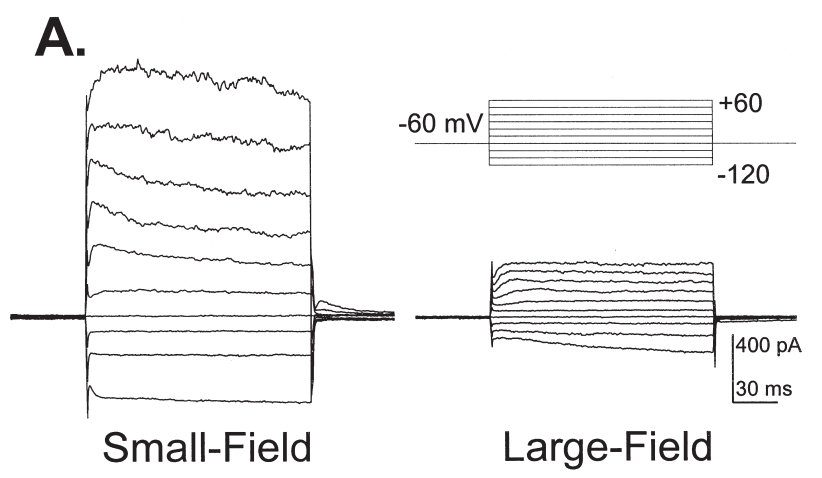

B.

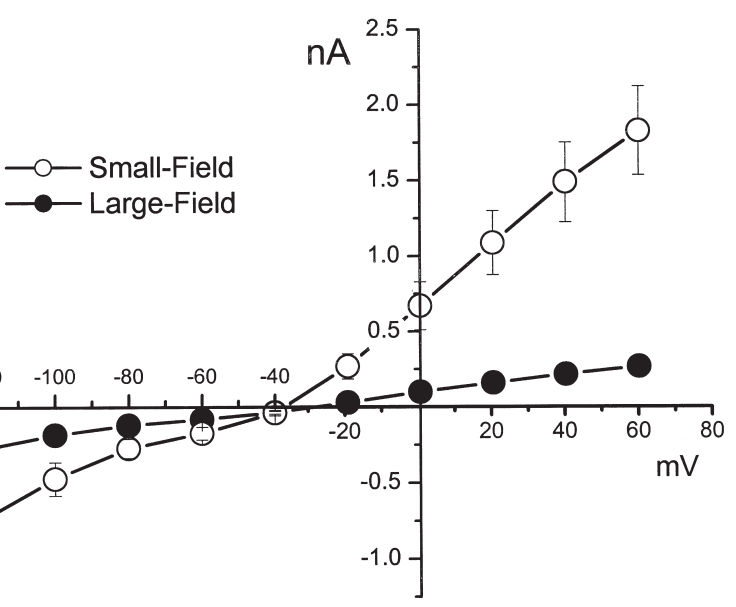

Figure 2. Voltage-activated membrane currents on small- and largefield bipolar cells. (A) Example of current traces elicited by the voltage protocol shown in the upper right-hand panel. (B) Averaged currentvoltage relationship for small- and large-field bipolar cells. Data points represent the average of 8 (small-field) and 12 (large-field) experiments; error bars $= \pm$ SEM. Note that the error bars for large-field bipolar cells are within the size of the symbols. 


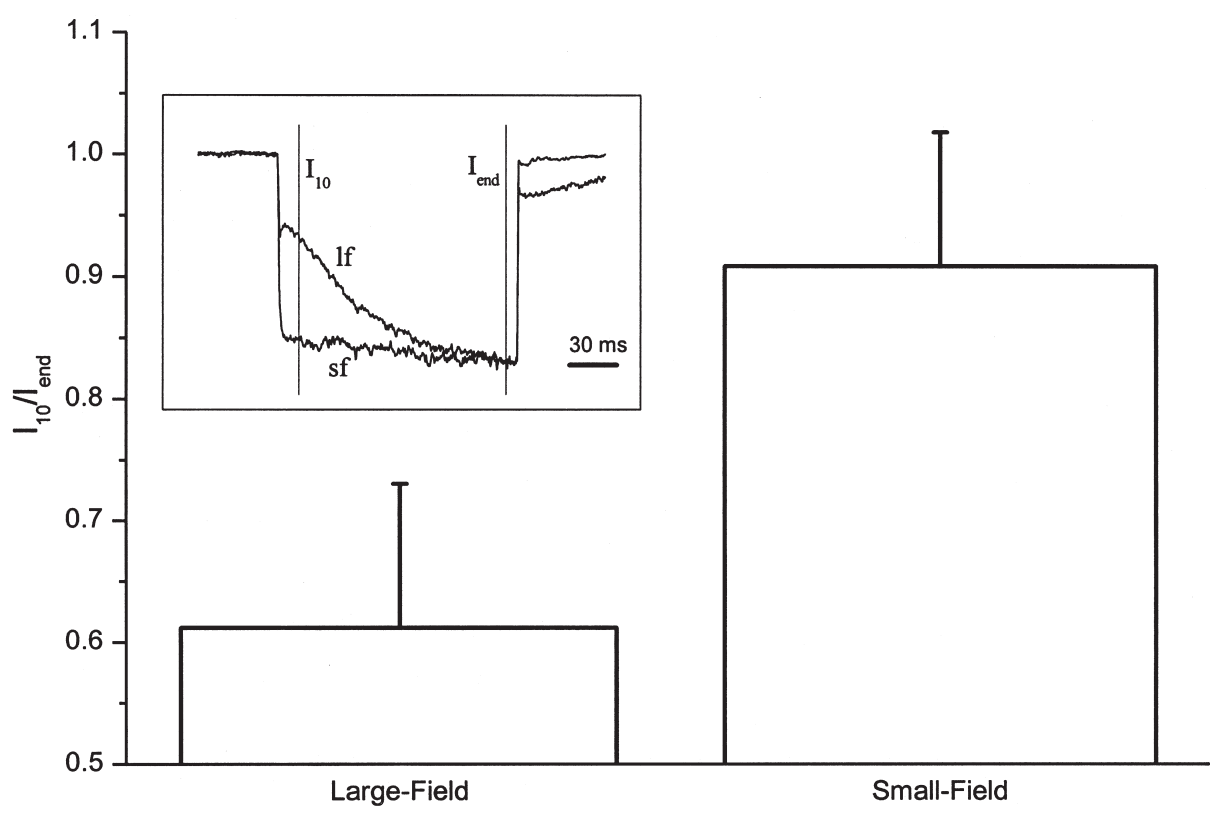

Figure 3. Comparison of the time course of the inward currents elicited by hyperpolarizing voltage steps from $-60 \mathrm{mV}$ to $-120 \mathrm{mV}$ for large-field and small-field bipolar cells. The inset shows typical responses from a small-field (sf) and a large-field (lf) cell and indicates the times ( $I_{10}$ and $\left.I_{\text {end }}\right)$ at which the measurements of the responses are made to calculate the ratios $I_{10} I_{\text {end }}$, which are graphed. The current amplitudes have been normalized to their peak values; error bars $= \pm$ SEM for the 8 and 12 experiments of Fig. 2.

whereas an equivalent voltage step imposed on large-field bipolar cells elicited a slowly developing inward current. To quantitate the difference, we calculated the ratio of the current amplitude measured $10 \mathrm{~ms}$ after onset of the hyperpolarizing voltage step $\left(I_{10}\right)$ to that measured at the end of voltage protocol $\left(I_{\text {end }}\right)$ for voltage steps from $-60 \mathrm{mV}$ to $-120 \mathrm{mV}$. For small-field bipolar cells, the ratio $\left(I_{10} / I_{\text {end }}\right)$ was $0.91 \pm 0.11(n=8)$, whereas for large-field bipolar cells, the ratio was $0.61 \pm 0.12(n=12)$.

A large component of the outward current induced by
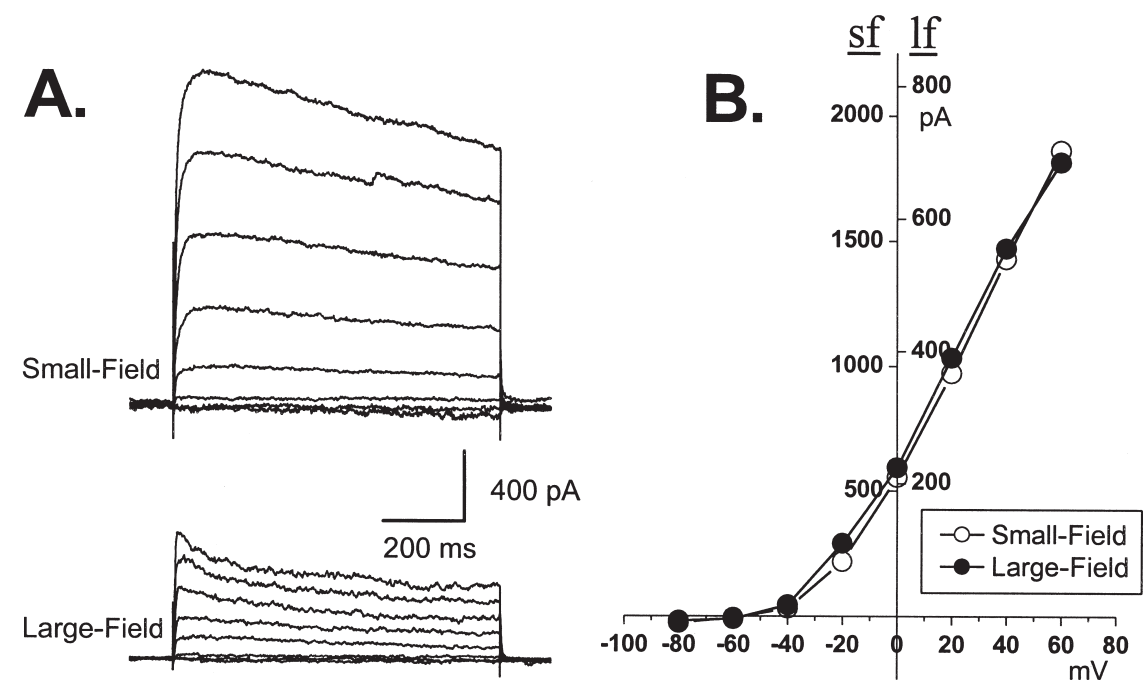

Figure 4. Comparison of the currents blocked by tetraethylammonium (TEA) in the two subtypes of skate bipolar cells. (A) The TEA-sensitive currents obtained by subtracting the membrane currents recorded in Ringer solution containing $20 \mathrm{~m} M$ TEA from the currents obtained in normal Ringer. (B) The I-V curves of the TEA-sensitive currents are equivalent for small- and large-field bipolar cells when they are adjusted to account for the different response amplitudes; sf = small-field, and lf $=$ large-field bipolar cell. 
depolarizing voltage was sensitive to tetraethylammonium (TEA). Figure 4A provides an example of the TEA-sensitive currents isolated from small- and large-field bipolar cells. They were obtained by subtracting the currents recorded in Ringer containing $20 \mathrm{mM}$ TEA from the currents obtained from the same cell in normal Ringer. Although the amplitudes of the TEA-sensitive currents differ significantly, they display a similar voltage activation profile; i.e., the I-V relationships are virtually identical after adjusting appropriately the scale of ordinates (Fig. 4B). The currents activate rapidly at depolarizing voltages $\geq-20 \mathrm{mV}$, they deactivate quickly after membrane repolarization, and the I-V relation appears to have a profile similar to that of the delayed rectifier (e.g., the Kv3 channel family) observed in many other preparations $(5,6)$.

In conclusion, the two morphologically distinct subtypes of bipolar cell seen in the all-rod skate retina also exhibit different profiles of voltage-activated potassium current. In previous studies, we have shown that these two types of cell also express different populations of neurotransmitter receptors (2). In particular, small-field bipolar cells are glycinesensitive, have a predominance of $\mathrm{GABA}_{\mathrm{A}}$ receptors, and give rise to large voltage-activated membrane currents. In contrast, the large-field bipolar cells do not respond to glycine, contain a larger proportion of $\mathrm{GABA}_{\mathrm{C}}$ receptors, and have small voltage-activated currents. The segregation of these properties into parallel pathways suggests that small-field bipolar cells are involved in the transmission of transient, high-intensity signals, whereas the large-field bipolar cells may be specialized for the transmission of sustained, low-intensity signals. Note that, in studies on the multitude of subtypes of bipolar cell in other vertebrate species, variations in voltage sensitivity $(7,8,9)$, kinetic properties (10), and receptor types (11) have been shown to affect the strength of the visual signal and its temporal and spatial characteristics. If the two morphologically distinct subtypes of bipolar cell in skate represent the only types present, the all-rod skate retina could provide an advantageous preparation with which to correlate membrane prop- erties with the physiological functions of the subtypes of bipolar cell.

\section{Acknowledgments}

This study was supported in part by NIH Grant EY-12028 (HQ); Fight for Sight, PSC/CUNY Grant 66257-0035, and NCRR/NIH RCMI Award RR-03037 (RLC); NIH Grant EY-06516 and a Senior Research Investigator Award from Research to Prevent Blindness (HR).

\section{Literature Cited}

1. Wu, S. M., F. Gao, and B. R. Maple. 2000. Functional architecture of synapses in the inner retina: segregation of visual signals by stratification of bipolar cell axon terminals. J. Neurosci. 20: 44624470.

2. Qian, H., H. Ripps, E. Schuette, and R. L. Chappell. 2001. Responses of small- and large-field bipolar cells to GABA and glycine. Brain Res. 893: 273-277.

3. Qian, H., L. Li, R. L. Chappell, and H. Ripps. 1997. GABA receptors of bipolar cells from the skate retina: actions of zinc on GABA-mediated membrane currents. J. Neurophysiol. 78: 2402-2412.

4. Schlemermeyer, E., and R. L. Chappell. 1996. Immunocytochemical evidence for ON and OFF bipolar cells in the retina of the skate, Raja erinacea. J. Neurocytol. 125: 625-635.

5. Malchow, R. P., H. H. Qian, H. Ripps, and J. E. Dowling. 1990. Structural and functional properties of two types of horizontal cell in the skate retina. J. Gen. Physiol. 95: 177-198.

6. Rudy, B., and C. J. McBain. 2001. Kv3 channels: voltage-gated $\mathrm{K}^{+}$ channels designed for high-frequency repetitive firing. Trends Neurosci. 24: $517-526$.

7. Connaughton, V. P., and R. Nelson. 2000. Axonal stratification patterns and glutamate-gated conductance mechanisms in zebrafish retinal bipolar cells. J. Physiol. 524: 135-146.

8. Hu, H. J., and Z. H. Pan. 2002. Differential expression of $\mathrm{K}^{+}$ currents in mammalian retinal bipolar cells. Vis. Neurosci. 19: 163173.

9. Ma, Y. P., J. Cui, H. J. Hu, and Z. H. Pan. 2003. Mammalian retinal bipolar cells express inwardly rectifying $\mathrm{K}^{+}$currents $\left(I_{K i r}\right)$ with a different distribution than that of $I_{h}$. J. Neurophysiol. 90: 3479-3489.

10. Awatramani, G. B., and M. M. Slaughter. 2000. Origin of transient and sustained responses in ganglion cells of the retina. J. Neurosci. 20: 7087-7095.

11. DeVries, S. H. 2000. Bipolar cells use kainate and AMPA receptors to filter visual information into separate channels. Neuron 28: 847856. 